\title{
The Use of Plea Bargain in Nigerian Criminal Law
}

\author{
Chinwe A. Mordi \\ Nigerian Law School, Augustine Nnamani Campus, Enugu, Nigeria \\ Email: chinwemordi@yahoo.co.uk
}

How to cite this paper: Mordi, C. A. (2018). The Use of Plea Bargain in Nigerian Criminal Law. Beijing Law Review, 9, 153-161.

https://doi.org/10.4236/blr.2018.92011

Received: February 4, 2018

Accepted: May 6, 2018

Published: May 9, 2018

Copyright $\odot 2018$ by author and Scientific Research Publishing Inc. This work is licensed under the Creative Commons Attribution International License (CC BY 4.0).

http://creativecommons.org/licenses/by/4.0/

\begin{abstract}
While previously unknown in the Nigerian criminal system, Plea bargain has come to stay with the establishment of the Economic and Financial Crimes Commission whose duty is to investigate and prosecute financial offenders. This papers seeks to establish the relationship between Plea-Bargain and Mediation as an alternative dispute resolution method and to advocate for a more developed system of plea bargain system in Nigeria.
\end{abstract}

\section{Keywords}

Plea-Bargain, Mediation, Nigeria

\section{Introduction}

Until recently, Nigerians were not familiar with the legal term "plea bargain" as it was not part of the Nigerian legal system. Plea bargain concept was surreptitiously smuggled into our statutory laws with the creation of the EFCC (Economic and Financial Crimes Commission) in 2004. This paper looks at the history and application of the concept of plea bargain in the Nigerian criminal law, and its comparative relationship with the concept of mediation, with the latter having a historical bearing on the Nigerian legal structure.

\section{Background}

Plea-bargain became known and applied with the establishment of the Economic and Financial Crimes Commission (EFCC) following increased level of corruption by virtue of Section 14(2) of the EFCC Act ${ }^{1}$.

Subject to the provision of Section 174 of the Constitution of the Federal Republic of Nigeria 1999 (which relates to the power of the Attor-

${ }^{1}$ Economic and Financial Crimes Commission (Establishment) Act, s. 14 
ney-General of the Federation to institute, continue or discontinue criminal proceedings against any persons in any court of law), the Commission may compound any offence punishable under this Act by accepting such sums of money as it thinks fit, not exceeding the amount of the maximum fine to which that person would have been liable if he had been convicted of that offence.

This concept of Plea Bargain was boldly institutionalized by the enactment of the Administration of Criminal Justice Law 2011, Laws of Lagos State ${ }^{2}$ in section 76 which provides that

"1) the prosecutor and a defendant or his legal practitioner may before the plea to the charge, enter into an agreement in respect of:

a) A plea of guilty by the defendant to the offence charged or a lesser offence of which he may be convicted on the charge, and

b) An appropriate sentence to be imposed by the Court if the defendant is convicted of the offence to which he intends to plead guilty.

2) The prosecutor may only enter into an agreement contemplated in Subsection (1) of this Section:

a) After consultation with the Police Officer responsible for the investigation of the case and if reasonably feasible, the victim, and

b) With due regard to the nature of and circumstances relating to the offence, the defendant and the interest of the community.

3) The prosecutor, if reasonably feasible shall afford the complainant or his representative the opportunity to make representations to the prosecutor regarding:

a) The contents of the agreement; and

b) The inclusion in the agreement of a compensation or restitution order.

4) An agreement between the parties contemplated in subsection (1) shall be reduced to writing and shall:

a) State that, before conclusion of the agreement, the defendant has been informed (i) that he has a right to remain silent; (ii) of the consequences of not remaining silent; (iii) that he is not obliged to make any confession or admission that could be used in evidence against him.

b) State fully the terms of the agreement and any admissions made and,

c) Be signed by the prosecutor, the defendant, the legal practitioner and the interpreter as the case may be.

5) The Presiding Judge, or Magistrate before whom criminal proceedings are pending shall not participate in the discussions contemplated in subsection (1). Provided that he may be approached by Counsel regarding the contents of the discussions and he may inform them in general terms of the possible advantages of discussions, possible sentencing options or the acceptability of a proposed agreement.

6) Where a plea agreement is reached by the prosecution and defence, the

${ }^{2}$ Administration of Criminal Justice Law, Laws of Lagos State, 2011. 
prosecutor shall inform the court that the parties have reached an agreement and the Presiding Judge or Magistrate shall then inquire from the defendant to confirm the correctness of the agreement.

7) The Presiding Judge or Magistrate shall ascertain whether the defendant admits the allegations in the charge to which he has pleaded guilty and whether he entered into the agreement voluntarily and without undue influence and May:

a) if satisfied that the defendant is guilty of the offence to which he has pleaded guilty, convict the defendant on his plea of guilty to that offence, or; b) if he is for any reason of the opinion that the defendant cannot be convicted of the offence in respect of which the agreement was reached and to which the defendant has pleaded guilty or that the agreement is in conflict with the defendant's rights referred to in subsection (4) of this Section, he shall record a plea of not guilty in respect of such charge and order that the trial proceed.

8) Where a defendant has been convicted in terms of subsection (7) (a), the Presiding Judge or Magistrate shall consider the sentence agreed upon in the agreement and if he is:

a) Satisfied that such sentence is an appropriate sentence impose the sentence; or

b) Of the view that he would have imposed a lesser sentence than the sentence agreed upon in the agreement impose the lesser sentence; or

c) Of the view that the offence requires a heavier sentence than the sentence agreed upon in the agreement, he shall inform the defendant of such heavier sentence he considers to be appropriate.

9) Where the defendant has been informed of the heavier sentence as contemplated in subsection.

8) Above, the defendant may:

a) Abide by his plea of guilty as agreed upon in the agreement and agree that, subject to the defendant's right to lead evidence and to present argument relevant to sentencing, the Presiding Judge, or Magistrate proceed with the sentencing; or

b) Withdraw from his plea agreement, in which event the trial shall proceed de novo before another Presiding Judge, or Magistrate, as the case maybe.

10) Where a trial proceeds as contemplated under subsection (9) (a) or de novo before another Presiding Judge, or Magistrate as contemplated in subsection (9) (b):

a) No reference shall be made to the agreement;

b) No admissions contained therein or statements relating thereto shall be admissible against the defendant; and

c) The prosecutor and the defendant may not enter into a similar plea and sentence agreement.

This brings about a situation where as described above, the accused and his 
counsel together with the prosecutor negotiate and agree on a charge acceptable to both parties and submit their agreement to the Judge to read as a judgment.

A prosecutor having charged a suspect with money laundering, knows that the suspect has received cash in excess of the limit permitted by law, armed with the bank statement of the suspect but lacking further proof of the final destination of the money, knows that he can secure a conviction of money laundering but will not be satisfied knowing that the judgment is empty as there are no properties or money to recover will attempt to reach a strike a plea deal with the suspect who on other hand lacks confidence that his assets are untraceable to surrender a percentage of the laundered money and or assets with which it purchased with the opportunity of facing reduced charges and upon conviction a reduced sentence.

The implication of plea-bargain is that it provides a win-win situation for both the State and the accused it is a win for the state in such a way that the conviction upon a plea bargain adds in number to the successful conviction by the state and on the other hand, a win for the suspect because he receives a reduced charge and sentence admitting the crime. This situation though noble in that it saves the time of the Court and saves the tax-payers money, presents to the writer a situation where in the hands of the judge are tied this means that the judge cannot give the maximum sentence for the crime admitted because to do that would mean a violation of the fundamentals of plea bargain, Thus the sentence that will then be given by the judge may be of ridiculously small proportion in relation to the crime committed.

Antagonists of the concept of plea bargain in criminal cases have argued that the practice violates the fundamental human rights of the accused by the inducement of confession of guilt and a trail waiver for the promise of a reduced sentence. Okwori in his article "Plea Bargaining: A Trial Procedure that Negates Fundamental Rights of the Accused Person" ${ }^{3}$ argued that the process of plea bargaining violates the following rights guaranteed under the US Constitution and the 1999 Constitution of Nigeria which are, the Presumption of innocence of the accused person until proven guilty, the right to fair hearing in public, the privilege against self-incrimination and the right to examination of witnesses. On the other hand, it is a well-established principle of criminal procedure in the United States, Section 36 of the 1999 Constitution of Nigeria and in Section 79 of the Administration of Criminal Justice Law, 2011 Laws of Lagos State, that persons arrested on suspicion of a crime are read the Miranda rights which developed from the case of Miranda v. Arizona ${ }^{4}$ which state that

You have the right to remain silent. Anything you say can and will be used against you in a court of law. You have the right to speak to an attorney, and to have an attorney present during any questioning. If you cannot af-

${ }^{3}$ Nicholson A. Okwori, Plea Bargaining: A Trial Procedure that Negates Fundamental Rights of the Accused, SAGE Publication, 2010.

${ }^{4}$ Miranda v. Arizona, 384 US 436 (1966). 
ford a lawyer, one will be provided for you at government expense.

The Miranda rights which is a US constitutional safeguard of the rights of a suspect gives the confidence that the accused was well informed of his right against self-incrimination for which he could either plead the $5^{\text {th }}$ amendment or request a lawyer which would defend him against the charges brought against him. The provision of the Miranda warning negates the position taken by Okwori as to the disadvantages of the use of Plea bargain in criminal trials furthermore, during a plea bargain which is entered into voluntarily, the accused is neither coerced, intimidated nor cajoled into accepting a plea. Furthermore, It has also been argued by Hallevy in his article "Is ADR (Alternative Dispute Resolution) Philosophy Relevant to Criminal Justice?-Plea Bargains as Mediation Process between the Accused and the Prosecution" 5 that plea bargaining privatizes the judiciary. He states that handing over the power to adjudge cases to individuals, in this case, the prosecutor and the accused counsel means turning the system of the judiciary over to individuals which is not and has never been the intention of the judiciary. In my opinion however, I do not see the criminal law system as being privatized but mediated because the judiciary still retains the right to accept or reject a plea.

Mediation is a practice whereby in a conflict, a third party seeks solutions to a problem or attempts to reduce the differences that exist with that conflict. The mediator usually takes the initiative in proposing terms of settlement ${ }^{6}$. This practice of alternative dispute resolution (ADR) differs from arbitration in such a way that the parties are not bound by an agreement to accept the suggestions made. Mediation is used in times when both parties intend to achieve a win-win resolution to the conflict.

The use of mediation in Nigeria dates back to the precolonial times, where it was used to resolve disputes between feuding families, communities and villages, the mediator was respected because of his standing in the community and in most occasions, his age. Mediation served well to maintain peace and preserve traditional values of the community ${ }^{7}$. This mode of dispute resolution has received judicial recognition in the case of Okpuruwu v. Okpokam ${ }^{8}$ where the Court of Appeal stated that the people of Nigeria had before the establishment of courts a simple and inexpensive way of resolving disputes between themselves. Since the precolonial era till date, Nigeria has developed its use of mediation through the adoption of various laws and establishment of bodies such as the multi-door court house established in Lagos, Nigeria. Most recently in the development of mediation in Nigeria, is the launch of the ICC Mediation Rules 2014. The said rules have been adapted to help parties resolve the most complex ${ }^{5}$ Okwori Gabriel Hallevy, Is ADR (Alternative Dispute Resolution) Philosophy Relevant to Criminal Justice? Plea Bargain as mediation Process between the Accused and the prosecution. ${ }^{6}$ Mediation, Encyclopeadia Britannica, 1999.

${ }^{7}$ A. O. Rhodes-Vivour, Mediation (A Face Saving Device) The Nigerian Perspective), IV. Journal of the International Bar Association Legal Practice Division Mediation Committee Newsletter, 2008, p. 1.

${ }^{8}(1998) 4$ NWLR Pt 90.554 at 586. 
situations quickly. Generally, alternative dispute resolution methods and in particular, mediation are favoured over litigation and even arbitration because it takes less time to reach a resolution ${ }^{9}$ the characteristics of mediation as an alternative dispute resolution method is that using it to resolve disputes saves time, saves cost and the parties negotiate their agreement usually in a way that favours both of them.

A plea bargain allows both parties to avoid a lengthy criminal trial and may allow the accused to avoid the risk of conviction at trial on a more serious charge. From the above, the principles of plea bargain which is synonymous with that of mediation can be summarized as follows:

1) Parties can negotiate on the terms/conditions of the agreement. That is, for criminal mediation, the parties through their counsel can decide that the accused will plead guilty to a lesser charge for a reduced sentence.

2) The plea bargain is at an advantage to the government who is usually on the benefiting end of this arrangement. This is because the hasty/speedy resolution of the case saves the government from spending tax-payers money also, properties/monies returned are returned to the government. It also, help to reduce the burden placed on the criminal justice system. Therefore, the parties achieve a win-win situation.

3) The parties make up the laws that guide the arrangement such as what charges to drop or keep and what sentences to lighten.

4) The Judge agrees/signs into judgement the "agreement" reached by the parties, and is bound by the agreement of the parties.

5) The option to participate in plea-bargain is voluntary. Parties cannot be forced into it. Same as in mediation because every Nigerian citizen has a right of access to the national courts.

The rise in economic and financial crimes in Nigeria has resulted in a corresponding rise in plea bargains. Many examples as settled in Nigerian courts come to mind. Amongst which are:

1) The recent conviction of Yusuf John Yakubu, a former Assistant Director of the Police Pension Board. Yusuf had been accused of embezzling about N23 billion from the Police Pension funds he was meant to oversee. Following a plea bargain arrangement, the accused entered a guilty plea on the three count charge and was sentenced to payment of a fine of N750,000.00 (N250,000.00) for each count ${ }^{10}$ and a the forfeiture of his assets acquired with the embezzled funds.

2) Former Governor Lucky Igbinedion went through a similar process. Lucky Igbinedion, the former Governor of Edo State was considered "lucky" indeed. Having being accused of looting about N 4.4 billion, he entered a plea bargain and at the end of the day, he was fined the sum of $\mathrm{N} 3.5$

\footnotetext{
${ }^{9}$ Mediation, International Chamber of Commerce.

${ }^{10}$ Ikechukwu Nnochiri, Pension Thief verdict: Justice Talba bags One Year Suspension without pay, Vanguard Newspaper, 2013.
} 
million while he forfeited three landed properties to the Federal Government ${ }^{11}$.

3) In the case of The Federal Republic of Nigeria v. Dr (Mrs) Cecilia Ibru ${ }^{12}$, Justice Dan Abutu of the Federal High Court sitting in Lagos, convicted Cecilia Ibru, the former managing director of Oceanic Bank plc, of a three-count charge of authorising loans beyond her credit limit, rendering false accounts and approving loans without adequate collateral. The court sentenced the accused to six months' imprisonment for each count, which ran concurrently, and ordered the forfeiture of related assets worth N191.4 billion $^{13}$. In adjudicating this case, the prosecution and accused agreed on plea bargain by relying on section 17 of the Federal High Court Act ${ }^{14}$ which encourages reconciliation among parties to facilitate amicable settlements in civil and criminal cases.

4) Also, former Governor of Bayelsa State, Governor Alamieyeseigha was charged for financial crimes and sentenced to 12 years in prison on a six -count charge. He was sentenced two years on each count but all sentences ran concurrently and the sentences ran from the day he was arrested and detained in $2005^{15}$. The above was as a result of plea bargain and because he has almost concluded two years in jail before brokering the bargain, he was released a few days after the judgment.

Comparatively, the Supreme Court of the United States of America supports the doctrine of plea bargain as early as 1971 by holding that Plea Bargaining is an essential component of the administration of justice. It should be encouraged if it can be properly administered because if every criminal charge was to be subjected to a full trial, the resources of the states and Federal Government will be overburdened (Santobello v. New York. 260) ${ }^{16}$. On the other hand, in France, there is a distinction between serious felonies (crimes) for which formal trials in the court of Assize are required from lesser offences (delits) which are triable under relaxed procedures in specialized courts called the correctional court. This distinction has given rise to charge reduction which is also called correctionalization where the prosecutor removes a case of crime to correctional court by treating it as a delit. Goldstein and Marcus claim that prosecutors regularly use this process 'avoid a judicial examination and a prolonged trial. They offer the accused a lesser sentence for a delict in exchange of the accused avoiding a full trial. ${ }^{17}$ This process is the same in Germany where offences are classified as minor but which include crimes such as embezzlement, fraud and receiving stolen goods may at the behest of the prosecutor be adjudicated by a penal order in

\footnotetext{
${ }^{11}$ The Sun News, 10 years on: EFCC gets knocks, mixed feelings, 2013, http://www.sunnewsonline.com.

${ }^{12}$ Federal Republic of Nigeria v. Dr (Mrs) Cecilia Ibru, Charge FHC/L.297C/2009.

${ }^{13}$ Omolola Coker, Plea Bargaining a developing trend in the Criminal Justice System, 2010.

${ }^{14}$ Cap F12, Federal High Court Act, Laws of Federation of Nigeria, 2004.

${ }^{15}$ K. Oladele, Vanguard Newspaper, Plea Bargaining and the Criminal Justice System in Nigeria, 2010, http://www.vanguardngr.com.

${ }^{16}$ Santobello v. Newyork 404 US 257 (1971).

${ }^{17}$ Goldstein and Marcus (1977).
} 
which the defendant waives his right to contest the charge and accept the penalty specified in the order ${ }^{18}$. The situation in Nigeria is closest to that of France and Germany which sees lesser charges such as white collar crimes pleaded to but more serious crimes such as felonies meriting the full trial by the courts.

While this paper is not to discuss the rightness or otherwise of the various situations of successful plea-bargain deals, it is clear that from the principles as adumbrated in the opening paragraph of the paper, the charges were duly and rightly plea-bargained. The discussion as above leads the writer to wonder whether plea-bargain cannot be rightly described as criminal mediation. It is pertinent to state at this juncture that as at the moment of writing this paper, there is nothing known in law as criminal mediation. But from a holistic read of the discussion above one can rightly say that plea bargain as practiced is in essence, criminal mediation because the parties make their own law as regarding their bargain such as what to concede to. Because the parties negotiate as to the terms of settlement, parties also determine what charges are appropriate in the circumstances as the charges admitted to directly affect the sentence given by the judge. The result of a successful plea-bargain is a "win-win" situation. It saves the time of the Court, saves tax-payers money and achieves the general reason for criminal prosecution which is to convict offenders.

\section{Conclusion}

In conclusion, while not being oblivious to the fact that this might be a an abomination in the eyes of the law to say that mediation, a world recognised successful method of dispute resolution can be equated with the cleverly devised means to get high profile blue collar offenders off from under the wrath of the law, the writer seeks to, by this paper stimulate the realities that may exist outside the law as we know it. To the writer therefore, the practice and procedure of plea-bargain bears resemblance to the practice and procedure of alternative dispute resolution specifically, mediation as a method of dispute resolution and as such can be regarded as criminal mediation. Furthermore, since mediation is here to stay and is recognised across jurisdictions and countries, it is proposed that for a better practice of plea bargain, the rules, procedures and punishments should be set out and passed into law. The mechanism of plea bargain should not be left to the whims and caprices of the legal practitioners.

\section{References}

Coker, O. (2010). Plea Bargaining, A Developing Trend in the Criminal Justice System. International Law Office. http://www.internationallawoffice.com

Mediation (1911). Encyclopeadia Britannica (11th ed., Vol. 18). http://academicguides.waldenu.edu/library

Nigeria, C. T. (1999). Constitution of the Federal Republic of Nigeria.

Nnochiri, I. (2013). Pension Thief Verdict: Justice Talba Bags One-Year Suspension without Pay. Vanguard Newspaper. http://www.vanguardngr.com

${ }^{18}$ Langbein (1979: 213-18). 
Okwori, N. A. (2010). Plea Bargaining: A Trial Procedure that Negates Fundamental Rights of the Accused Person (pp. 1-12). https://doi.org/10.2139/ssrn.1629255

Oladele, K. (2010). Plea Bargaining and the Criminal Justice System in Nigeria. Vanguard Newspaper: http://www.vanguardngr.com

Rhodes-Vivour, A. O. (2008). Mediation (A Face Saving Device). The Nigerian Perspective. Journal of the International Nar Legal Practice Association Legal Practice Division Mediation Committee Newsletter, 1.

The Sun News (2013) 10 Years on: EFCC Gets Knocks, Mixed Feelings. http://www.sunnewsonline.com 